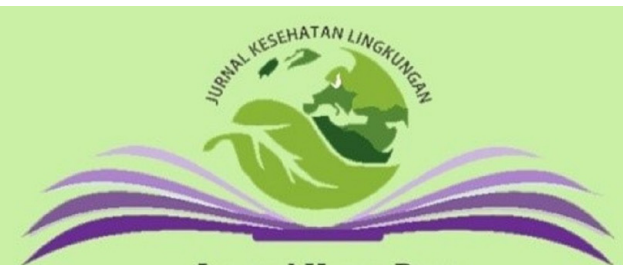

Journal Home Page:

https://e-journal.unair.ac.id/JKL

\section{Jurnal Kesehatan Lingkungan}

Vol. 14 No. 1

DOI: $10.20473 /$ jkl.v14il.2022.27-36

ISSN: 1829 - 7285

E-ISSN: 2040 - 881X

\title{
THE DIFFERENCES IN BLOOD LEAD LEVELS IN WOMEN WITH GESTATIONAL HYPERTENSION OR PRE-ECLAMPSIA AND WOMEN WITH NORMAL PREGNANCY (A STUDY IN THE NORTH COAST OF JAVA, BREBES DISTRICT)
}

Suhartono Suhartono ${ }^{1 *}$, Apoina Kartini², Budiyono Budiyono ${ }^{1}$, Yusniar Hanani Darundiati $^{1}$

${ }^{1}$ Department of Environmental Health, Faculty of Public Health, Diponegoro University, Semarang 50275, Indonesia

${ }^{2}$ Department of Public Health Nutrition, Faculty of Public Health, Diponegoro University, Semarang 50275, Indonesia

\section{Corresponding Author:}

*)suhartono_damas@yahoo.com

\section{Article Info}

Submitted : 20 November 2021

In reviewed : : 13 December 2021

Accepted :30 December 2021

Available Online : 31 January 2022

Keywords : Blood lead levels, Pregnant women, Gestational hypertension, Pre-eclampsia

Published by Fakultas Kesehatan Masyarakat Universitas Airlangga

\begin{abstract}
Introduction: Gestational Hypertension (GH) and Pre-eclampsia (PE) are the leading causes of maternal death. Exposure to lead from the environment, especially agricultural activities, may cause pregnant women to suffer from GH and PE. GH/ $P E$ may occur through oxidative stress mechanisms and progressive endothelial damage. Brebes District is one of the areas with the highest Maternal Mortality Rate (MMR) in Central Java where the occurrence of GH/PE was a lot. This study aimed to analyze the differences in Blood Lead Levels (BLL) in pregnant women with GH/PE and normal pregnant women in Brebes District. Methods: This study used a cross-sectional design. By selecting and applying inclusion criteria, 18 subjects were selected for the GH/PE group (case group), and 46 subjects were selected for the normotension group (control group). Measurement of BLL was carried out using the Atomic-Absorption Spectrometry (AAS). Some of the statistical methods used were independent t-test, Mann-Whitney test, Chi-square test, multivariate logistic regression test, and Rank-Spearman correlation test. The risk estimate was calculated from the Odds-Ratio (OR) and 95\% Confidence Interval (CI). Results and Discussion: The median value and range of the BLL in the case and control groups were $40.20 \mathrm{~g} / \mathrm{dL}$ (15.50-89.20) and $32.75 \mathrm{~g} / \mathrm{dL}$ (3.60-42.80), respectively $(p=0.011)$. Pregnant women with the BLL of $\geq 35.15 \mathrm{~g} / \mathrm{dL}$ had eight times the risk of experiencing GH/PE (Adj-OR $=8.1 ; 95 \% C I=1.7-39.0)$. Exposure to lead will increase the production of Reactive Oxygen Species (ROS), resulting in oxidative stress and endothelial dysfunction in addition to increasing the blood pressure. Conclusion: The BLL in pregnant women with GH/PE is higher than women with normal pregnancy, and the BLL in the high category is a risk factor for GH/PE.
\end{abstract}

\section{INTRODUCTION}

Maternal death occurs during pregnancy and childbirth or within 42 days of termination of pregnancy. It is still a health problem worldwide, especially in developing countries. Every day, around 810 women die during pregnancy or childbirth (1). In addition to bleeding and infection after delivery, the leading cause of maternal death is an increase in blood pressure after 20 weeks of gestation, known as Gestational Hypertension $(\mathrm{GH})$ or Pre-eclampsia (PE) (2-3). GH is a systolic blood pressure (SBP) of at least $140 \mathrm{mmHg}$ and/or a Diastolic Blood Pressure (DBP) of at least $90 \mathrm{mmHg}$ after the 20th week of pregnancy. If the increase in blood pressure is accompanied by proteinuria, it is referred to PE (4). The data show GH/PE accounts for about $18 \%$ of maternal deaths globally or around 62,000 to 77,000 deaths per year (4-5).

The pathophysiology of $\mathrm{GH} / \mathrm{PE}$ is still unclear, but disturbances in the process of placentation in early pregnancy followed by an inflammatory process and progressive endothelial damage are strongly suspected as the disorder (6-7). Some of the risk factors for $\mathrm{GH} /$ $\mathrm{PE}$ that have been widely discussed are primiparas, history of hypertension or impaired renal function before pregnancy, history of hypertension or GH/PE in previous pregnancies, diabetes, obesity, age over 40 years, multiple pregnancies, family history of PE, and so on (5-8). Several recent studies have shown that environmental factors have the potential to trigger the incidence of $\mathrm{GH} /$ $\mathrm{PE}$, including exposure to toxic materials e.g., pesticides (9-10) and heavy metals, such as lead or plumbum $(\mathrm{Pb})(11-12)$. An increase in Blood Lead Levels (BLL) is followed by the rise in blood pressure of pregnant women (13), through oxidative stress mechanisms. Increased Reactive Oxygen Species (ROS) (14) in the mechanism triggers endothelial dysfunction and increases blood pressure (15-16).

Data from ASEANstats showed that the Maternal Mortality Rate (MMR) in Indonesia in 2014 was still relatively high at 190/100,000 live births (17) and still 
far from the Sustainable Development Goal's (SDGs) target at $70 / 100,000$ live births by 2030 (18). The MMR in Indonesia is better than Laos and Myanmar but the rest of South East Asia regions (17). Central Java is one of the provinces that has the largest MMR in Indonesia (19), which is at $76.9 / 100,0000$ live births (20) ranked second nationally (19).

In 2019, Brebes District, located on the Northern Coast of Java, is the highest contributor to maternal mortality in Central Java, having 37 cases (20). Data from the Brebes District Health Office showed that one of the main causes of maternal mortality in this area is $\mathrm{GH} / \mathrm{PE}$ at $67.7 \%$ (21). Environmental factors (pollution), one of which is exposure to lead, are likely suspected of contributing to the high rate of $\mathrm{GH} / \mathrm{PE}$ incidence in Brebes District. The exposure to lead may come from industrial, transportation, and agricultural activities.

In everyday life, exposure to lead comes from sanding paint or house dust, eating and drinking utensils, cosmetics, glass pots, soil and drinking water from lead pipes, faucets, and plumbing fixtures (22). Several studies on the North Coast of Java have also proven that other potential risks of exposure include fish (23), vegetables, especially shallots (24), which are the main agricultural commodities in Brebes District. In addition to industrial activities and transportation, agriculture, and battery recycling activities in the area might be the main source of lead (25). The transmission routes of lead mainly occur as pregnant women get involve in agricultural activities and consume lead contaminated food or beverages daily. This study aimed to analyze the differences in BLL in pregnant women with GH/PE and women with normal pregnancy. Besides, it proved whether the high BLL is a risk factor for $\mathrm{GH} / \mathrm{PE}$ in pregnant women.

\section{METHODS}

This study is an analytic observational study with a cross-sectional design. The target population was all pregnant women in the North Coast of Java. The accessible population was pregnant women who were registered at two primary healthcare centers in the North Coast of Java, Brebes district, in September and October 2017. In total, there were 275 people. The primary healthcare centers were chosen because they had the highest number of pregnant women among the areas of the coast. To control the confounding variables, inclusion criteria were applied for the subjects such as age of subjects at 20-35 years, the gestational age of $>20$ weeks, and singleton pregnancy.

The data obtained from the primary health care centers showed out of 275 pregnant women, $179(65.1 \%)$ met the inclusion criteria, and 24 of them (13.4\%) were the case $(\mathrm{GH} / \mathrm{PE})$ group for having the Systolic Blood Pressure (SBP) of $140 \mathrm{mmHg}$ or more, or Diastolic Blood Pressure (DBP) of $90 \mathrm{mmHg}$ or more, or both, with or without proteinuria. While out of 155 subjects with normotensive, 50 subjects were randomly selected as the control (normotensive) group. Of 24 subjects in the GH/PE group, six subjects refused to participate in the study for fear of having blood collection, while in the control group 4 subjects refused to participate for the same reason. The analysis was carried out to 18 subjects in the GH/PE group and 46 subjects in the normal group. The flow chart of the subjects selection can be seen in Figure 1.

The data on increased Blood Pressure (BP) above 140/90 $\mathrm{mmHg}$ after 20 weeks of gestation were taken from the medical records during the Antenatal Care (ANC) there. The medical records were done by trained health personnel (midwives). The use of medical records determined whether the subjects were in the $\mathrm{GH} / \mathrm{PE}$ group or the normal pregnancy group. In carrying out the research, BP measurements were also carried out (as a cross-check and referred to current BP) by trained research members, using the Microlife digital sphygmomanometer. The measurements were repeated thrice and averaged automatically. Anthropometric measurements (height and weight) were performed using the Seca $₫ 213$ stadiometer and Seca $\AA 813$ electric flat scale.

The measurements of BLL were carried out using the Atomic-Absorption Spectrometry (AAS) method by the GAKY Laboratory, Faculty of Medicine, Universitas Diponegoro. Information about the characteristics of the subjects (age, maternal education level, maternal occupation), the number of pregnancies (gravida), family history of hypertension, and family history of Diabetes Mellitus (DM) was taken during interview using a structured questionnaire. Data were analyzed using SPSS version 20 software.

Some of the statistical methods used were independent t-test, Mann-Whitney test, Chi-square test, multivariate logistic regression test, and Rank-Spearman correlation test. The risk estimate was calculated from the Odds-Ratio (OR) and 95\% Confidence Interval $(\mathrm{Cl})$. To determine the cut-off value of women's ages, Body Mass Index (BMI), and BLL as predictors/risk factors for $\mathrm{GH} / \mathrm{PE}$, the Receiver Operating Characteristic (ROC) curve method was used. The Area Under Curve (AUC), sensitivity and specificity values were considered to determine the cut-off value (26). A multivariate logistic regression test using the Backward Wald method was 
used to identify the main risk factors for $\mathrm{GH} / \mathrm{PE}$ from the three candidate variables, i.e., maternal age, BMI, and BLL (27). The research was approved by the Medical Research Ethics Committee of the Faculty of Medicine, Universitas Diponegoro (No. 664/ EC/FK-RSDK/ $\mathrm{XI} / 2017)$.

\section{RESULTS}

Even though the inclusion criteria for women's age was applied (20-35 years old), it turned out that the $\mathrm{GH} / \mathrm{PE}$ group was mostly older than the normal group. There was a significant difference in ages between $\mathrm{GH} /$ PE and normal groups ( $p$-value $<0.001$ ).

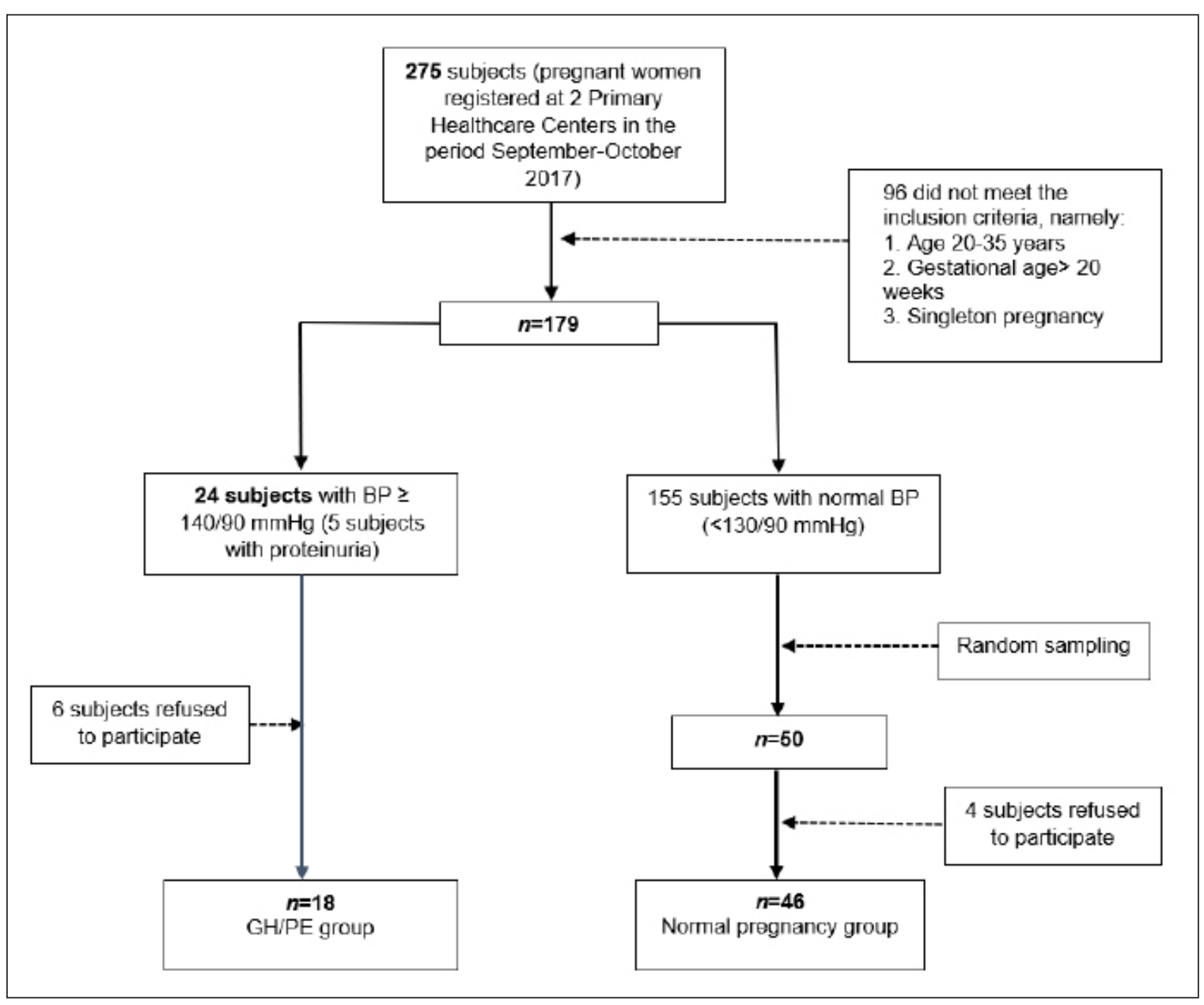

Figure 1. Selection of Research Subjects

The data showed that the gestational age and height of the subjects were relatively the same in both groups ( $p=0.970 ; p=0.747$, respectively). However, the $\mathrm{BMI}$ in the case $(\mathrm{GH} / \mathrm{PE})$ group was higher than the control (normotensive) group $(p=0.018)$ (Table 1). The results showed there was a significant difference in current systolic and diastolic blood pressures between the case and control groups ( $p<0.001$ for both). Regarding maternal education level, gravida, maternal occupation, family history of hypertension, and family history of DM, there were no significant differences between the two groups ( $p>0.05$ for both).

The Mann-Whitney U-test proved that the BLL in the case group was higher compared to the control group $(p=0.011)$. The median value and range of $B L L$ in the case and control group were $40.20 \mathrm{~g} / \mathrm{dL}$ (15.50-89.20) and $32.75 \mathrm{~g} / \mathrm{dL}$ (3.60-42.80), respectively (Figure 2 ).

Regarding age, BMI, and BLL between the groups, the cut-off values were determined using the ROC curve (Figure 3). The results obtained a value of 31.5 years for maternal age $(A \cup C=0.809$; sensitivity $=$ 88.9; specificity $=76.1), 28.4 \mathrm{~kg} / \mathrm{m}^{2}$ for $B M I$ ( $A \cup C=0.708$; sensitivity $=72.2$; specificity $=63.0$ ), and $35.15 \mu \mathrm{g} / \mathrm{dL}$ for BLL $(A \cup C=0.707$; sensitivity $=72.2$; specificity $=69.6$ ). There were significant relationships between age, BMI, and BLL with the incidence of GH/PE ( $p<0.05$ for both) (Table 2). 
Table 1. Characteristics of GH/PE and Normal Groups

\begin{tabular}{|c|c|c|c|}
\hline Characteristics & $\begin{array}{c}\text { GH/PE } \\
\text { Group } \\
(n=18)\end{array}$ & $\begin{array}{c}\text { Normal } \\
\text { Group } \\
(n=46)\end{array}$ & P-values \\
\hline Age (years) & $33.1 \pm 1.97$ & $28.4 \pm 4.52$ & $<0.001^{\mathrm{a}}$ \\
\hline Gestational ages (weeks) & $25.5(21-40)$ & $27.0(21-38)$ & $0.970^{\mathrm{b}}$ \\
\hline Weight* (kg) & $71.2 \pm 12.09$ & $63.4 \pm 12.10$ & $0.024^{\mathrm{a}}$ \\
\hline Height* (cm) & $153.5 \pm 5.53$ & $153.0 \pm 5.06$ & $0.747^{\mathrm{a}}$ \\
\hline BMI $\left(\mathrm{kg} / \mathrm{m}^{2}\right)$ & $30.1 \pm 4.14$ & $27.0 \pm 4.67$ & 0.018 \\
\hline \multicolumn{4}{|l|}{ Current Blood Pressure } \\
\hline Systolic (mmHg) & $158.9 \pm 16.34$ & $109.1 \pm 13.80$ & $<0.001^{\mathrm{a}}$ \\
\hline Diastolic (mmHg) & $99.4 \pm 11.40$ & $68.6 \pm 10.46$ & $<0.001^{\mathrm{a}}$ \\
\hline \multicolumn{4}{|l|}{ Maternal education level } \\
\hline Elementary school & $11(61.1 \%)$ & $26(56.5 \%)$ & $0.660^{\mathrm{c}}$ \\
\hline Junior high school & $7(38.9 \%)$ & $18(39.1 \%)$ & \\
\hline Senior high school & $0(0.0 \%)$ & $2(4.3 \%)$ & \\
\hline \multicolumn{4}{|l|}{ Gravida } \\
\hline Primigravida & $1(5.6 \%)$ & $12(26.1 \%)$ & $0.136^{\mathrm{c}}$ \\
\hline Multigravida & $17(94.4 \%)$ & $34(73.9 \%)$ & \\
\hline \multicolumn{4}{|l|}{ Maternal Occupation } \\
\hline Housewife & $11(61.1 \%)$ & $36(78.3 \%)$ & $0.054^{\mathrm{c}}$ \\
\hline Private Employees & $2(11.1 \%)$ & $0(0.0 \%)$ & \\
\hline Farmer & $5(27.8 \%)$ & $10(21.7 \%)$ & \\
\hline \multicolumn{4}{|l|}{$\begin{array}{l}\text { Family History of } \\
\text { Hypertension }\end{array}$} \\
\hline Yes & $7(38.9)$ & $16(34.8)$ & $0.986^{\mathrm{c}}$ \\
\hline No & $11(61.1)$ & $30(65.2)$ & \\
\hline \multicolumn{4}{|l|}{$\begin{array}{l}\text { Family History of Diabetes } \\
\text { Mellitus }\end{array}$} \\
\hline Yes & $2(11.1)$ & $6(13.0)$ & $1.000^{\mathrm{c}}$ \\
\hline No & $16(88.9)$ & $40(87.0)$ & \\
\hline
\end{tabular}

Notes: values $=$ mean $\pm S D$; median (range); and frequencies, $n(\%)$. ${ }^{a}$ Independent t-test, ${ }^{b}$ Mann-Whitney test, ${ }^{c}$ Chi-square

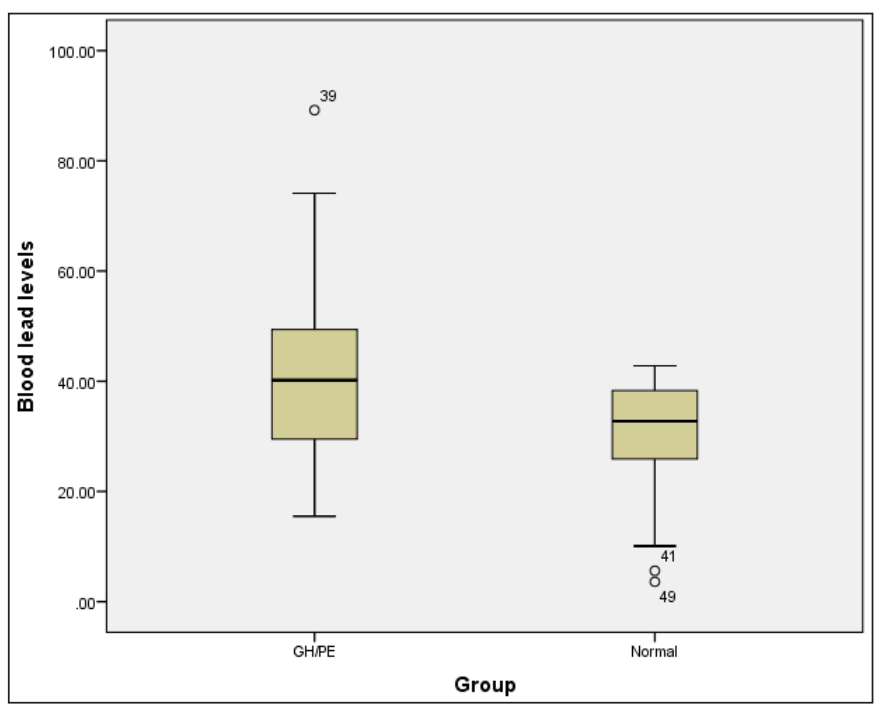

Figure 2. The Differences in BLL between GH/PE and Normal Group

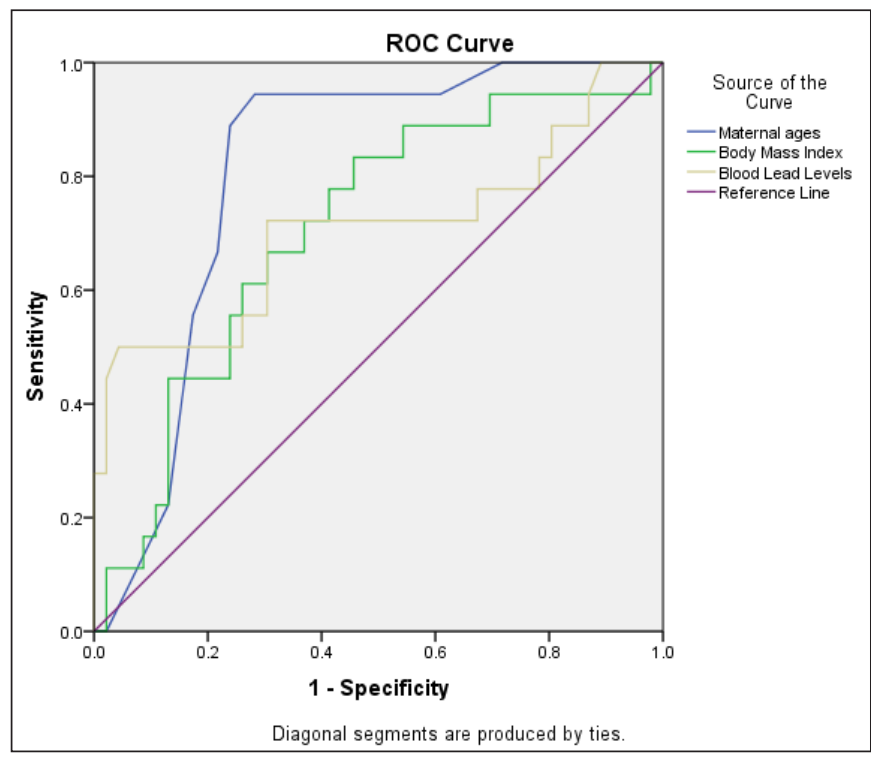

Figure 3. The ROC Curve for the Determination of Maternal Age, BMI, and BLL Cut-Off Values

Table 2. The Association between Maternal Age, BMI, and BLL and the Incidence of GH/PE

\begin{tabular}{|c|c|c|c|c|}
\hline Variables & $\begin{array}{c}\text { GH/PE } \\
\text { Group } \\
(n=18)\end{array}$ & $\begin{array}{c}\text { Normal } \\
\text { Group } \\
(n=46)\end{array}$ & p-values & $\begin{array}{c}\text { OR } \\
(95 \% \text { CI })\end{array}$ \\
\hline \multicolumn{5}{|l|}{$\begin{array}{l}\text { Maternal age } \\
\text { (years) }\end{array}$} \\
\hline$\geq 31.5$ & $16(88.9)$ & $11(23.9)$ & $<0.001$ & $25.4(5.0-128.4)$ \\
\hline$<31.5$ & $2(11.1)$ & $35(76.1)$ & & \\
\hline \multicolumn{5}{|l|}{ BMI $\left(\mathrm{kg} / \mathrm{m}^{2}\right)$} \\
\hline$\geq 28.4$ & $13(72.2)$ & $17(37.0)$ & 0.024 & $4.4(1.3-14.6)$ \\
\hline$<28.4$ & $5(27.8)$ & $29(63.0)$ & & \\
\hline \multicolumn{5}{|l|}{ BLL $(\mu \mathrm{g} / \mathrm{dL})$} \\
\hline$\geq 35.15$ & $13(72.2)$ & $14(30.4)$ & 0.006 & $5.9(1.8-19.9)$ \\
\hline$<35.15$ & $5(27.8)$ & $32(69.6)$ & & \\
\hline
\end{tabular}

The results of the multivariate logistic regression test using the Backward Wald method showed two variables were the independent risk factors for $\mathrm{GH} /$ $P E:$ age of $\geq 31.5$ years and $B L L$ of $\geq 35.15 \mathrm{~g} / \mathrm{dL}$ (Table 3). To analyze the potential role of age, BMI, and BLL in increasing blood pressure, a correlation test was conducted between these variables and BP variables (systolic/diastolic blood pressures). The Rank-Spearman test showed a significant correlation between age and BMI ( $p<0.001 ; r=0.442)$, age and SBP $(p<0.001$; $r=0.582)$, and age and DBP $(p<0.001 ; r=0.491)$. Meanwhile, for BLL, although it was not significant, it was positively correlated with BMI $(p=0.067 ; r=0.231)$, SBP 
$(p=0.113 ; r=0.200)$, and DBP $(p=0.224 ; r=0.154)$. The results of the Rank-Spearman correlation test are presented in Table 4.

Table 3. The Results of Multivariate Logistic Regression

\begin{tabular}{lccccc}
\hline Variables & B & SE & Wald & $\mathbf{p}$ & $\begin{array}{c}\text { Adj-OR } \\
(\mathbf{9 5 \%} \text { CI) }\end{array}$ \\
\hline Maternal ages & 3.452 & 0.915 & 14.229 & $<0.001$ & $31.5(5.2-189.6)$ \\
BLL & 2.087 & 0.804 & 6.734 & 0.009 & $8.1(1.7-39.0)$ \\
Constant & -4.057 & 0.973 & 17.388 & $<0.001$ & \\
\hline
\end{tabular}

Table 4. The Correlation between Maternal Age, BMI, BLL, SBP, and DBP

\begin{tabular}{lcccc}
\hline & BMI & BLL & SBP & DBP \\
\hline Maternal Ages & $0.442 ;<0.001$ & $0.156 ; 0.218$ & $0.582 ;<0.001$ & $0.491 ;<0.001$ \\
BMI & - & $0.231 ; 0.067$ & $0.513 ;<0.001$ & $0.399 ; 0.001$ \\
BLL & $0.231 ; 0.067$ & - & $0.200 ; 0.113$ & $0.154 ; 0.224$ \\
\hline
\end{tabular}

Notes: values according to the correlation coefficient ( $r$ ) and $p$-values

\section{DISCUSSION}

The results showed that the BLL in the case $(\mathrm{GH} /$ $\mathrm{PE})$ group was higher than the normotensive pregnant women group. The high BLL $(\geq 35.15 \mu \mathrm{g} / \mathrm{dL})$ was an independent risk factor for the incidence of GH/PE. The multivariate logistic regression test proved that pregnant women with $B L L$ of $\geq 35.15 \mu \mathrm{g} / \mathrm{dL}$ had eight times the risk of experiencing GH/PE. Research in Saudi Arabia found the same results that $B L L$ in women with $P E$ was greater than normal pregnant women (28). A cohort study in Sweden showed the exposure to low lead level increases blood pressure and the risk of experiencing hypertension in the age group of 46-67 years (29). Exposure to lead which may increase blood pressure was also proven by research on car painting workers in Surabaya (30).

The current examination showed very high levels of BLL with the median value of $40.20 \mu \mathrm{g} / \mathrm{dL}$ in the $\mathrm{GH} / \mathrm{PE}$ group and $32.75 \mu \mathrm{g} / \mathrm{dL}$ in the normal group. The value was lower than that of women in Nigeria which was $64.3 \mu \mathrm{g} / \mathrm{dL}$ (31), but higher than that of women in Saudi Arabia which was below $30.0 \mu \mathrm{g} / \mathrm{dL}$ (28). Research in Taiwan showed much lower results, where the normal pregnant women had $2.38 \mathrm{~g} / \mathrm{dL}$, and the PE group has $3.42 \mathrm{~g} / \mathrm{dL}(12)$.

The main source of lead in the research sites probably came from contaminated food, especially marine products and vegetables. Besides, as women got involved in agricultural activities, they likely got exposed to lead which increased their BLL levels. Research in the agricultural area of Brebes district proved that the lead content in soil and vegetables exceeds the minimum threshold value (32). Several types of pesticides that are often used in the Brebes shallot farming areas contain lead (33).
Regarding exposure to lead, there is no safe limit for BLL in pregnant women and children (34). Even the slightest exposure to lead should be avoided. Exposure to lead in small but continuous doses (long term) harms the body as lead enters through the respiratory tract (inhalation) and the digestive tract (oral). It causes bioaccumulation of lead in the body which will be stored in the bones (35). In pregnant women, the need for calcium increases, especially to support fetal growth (36-37). When the calcium intake is inadequate, calcium cannot be maintained in the bones (bone decalcification). Followed by the release of lead in the bones, BLL will increase (38-39). The insufficient intake of calcium may be one of the causes of the high BLL in pregnant women in the research subjects.

$\mathrm{GH} / \mathrm{PE}$ is a health problem in pregnant women whose pathophysiology is unclear $(7,40)$. One of the causes is oxidative stress (41-42). Exposure to lead causes an increase in the production of Reactive Oxygen Species (ROS) which triggers the oxidative stress. Oxidative stress leads to endothelial function disorders and increased blood pressure. The increase in ROS causes the Nitric Oxide (NO), which is a vasodilator, to become inactive, thereby increasing intraarterial pressure and lowering NO production (16). The disturbances in these three components (increased ROS, raise arterial pressure, and lower NO production) cause an increase in peripheral vascular resistance along with increased blood pressure (43).

The experimental studies in animals have shown that exposure to lead can increase plasma norepinephrine and downregulate adrenergic receptors, thereby stimulating the sympathetic nervous system and leading to an increased vasoconstrictive response (41). Lead also interferes with the function of the Na/K-ATPase pump which plays a role in maintaining intracellular calcium balance. It is able to affect the sodium gradient and the activity of the sodium/calcium exchanger, which increases intracellular calcium and the smooth muscle cells contractility (44).

Several reviews have shown that pregnant women with GH/PE have low NO levels, increased ROS, and endothelial dysfunction (45-46). The positive relationship between $\mathrm{GH} / \mathrm{PE}$ and $\mathrm{BLL}$, proven by pathogenic studies, suggests that exposure to leads contributes to the pregnancy complications $(11,12)$.

Besides, the current study also found other variables that could potentially became risk factors for GH/PE, namely maternal age and BMI. The cut-off value calculation for the age variable showed that age of $>$ 31.5 years was a risk factor for GH/PE. Research proved 
that age over 35 years is a risk factor for PE (47). While the results of this study obtained a younger age limit (31.5 years old), this was probably due to differences in ethnicity and the risk of exposure to toxic substances in the environment.

Meanwhile, for the BMI variable, the gestational age and maternal height were relatively the same in both groups ( $\mathrm{GH} / \mathrm{PE}$ and normal pregnancy); the weight of the subjects in the case (GH/PE) group was greater, so was BMI. The difference in these variables between the groups was significant. This study revealed BMI of > 28.4 increased the risk of GH/PE. Several studies have shown that the excessive weight gain in pregnant women increases the risk of GH/PE (48-49). The excessive weight gain during pregnancy is likely associated with chronic inflammatory conditions, which surges plasma levels of C-reactive protein, inflammatory cytokines (5052), and a systemic inflammatory response characterized by increased ROS that damages endothelium cells in blood vessels, resulting in clinical symptoms of GH/PE (53-54).

This study showed a positive correlation between BLL and BMI (Table 4). Similarly, a study in China found BLL is independently associated with BMI of women (55), while the other study concluded children whose mothers had elevated $\mathrm{BLL}(\geq 5.0 \mu \mathrm{g} / \mathrm{dL})$ are more likely to be overweight or obese (56). The increase in BMI because of exposure to lead is likely related to oxidative stress which disrupts endocrine function and body fat metabolism (57). Meanwhile, another theory proposes the alterations in the hypothalamic-pituitary-adrenal axis, stress-induced increase in glucocorticoid levels, oxidative stress, and the changes in lipid metabolism (49).

Lead is also hematotoxin which interferes with hemoglobin $(\mathrm{Hb})$ synthesis, causing anemia via the inhibition of ferrochelatase and $\delta$-aminolaevulinic acid dehydratase (ALAD) among many enzymes involved in heme biosynthesis (58). Several studies on the impact of exposure to lead on the blood system, both in adults and children, have been carried out. Research in India proved that BLL in pregnant women with anemia is greater than in non-anemic pregnant women (59). Anemia in pregnant women needs to be prevented because it causes impaired fetal growth, low birth weight or small for gestational age (60), and increased risk of maternal and perinatal mortality (61).

In addition to the occurrence of GH/PE, exposure to lead impacts the fetus, especially fetal growth and development (62-63). Research showed an increase of $1 \mu \mathrm{g} / \mathrm{dl}$ BLL was associated with changes in birth weight of $-9.93 \mathrm{~g}$, head circumference $-0.03 \mathrm{~cm}$, and crownheel length of $-0.05 \mathrm{~cm}(64)$. A systematic review found that exposure to lead is a risk factor for Attention Deficit Hyperactivity Disorder (ADHD) in children (65-66). Research in Korea revealed that children with BLL above $2.30 \mu \mathrm{g} / \mathrm{dL}$ were at a 2.5 -fold greater risk of having ADHD (66). Another study concluded that maternal BLL in late pregnancy of $<5 \mathrm{mg} / \mathrm{dL}$ affected the neurodevelopment of children up to 36 months of age (67). These results prove that even in low exposure, the toxic nature of lead is a serious problem for children's growth and development.

To reduce maternal mortality, the Indonesian Ministry of Health needs to take intoaccountenvironmental factors, e.g., lead as one of the toxic materials which can trigger the incidence of GH/PE in pregnant women. In high-risk areas for exposure to lead (e.g., industrial or agricultural areas), it is necessary to carry out BLL examination on pregnant women in the first trimester, especially in the age group above 30 years. Even earlier screening should be carried out to check BLL in women who have pregnancy planning.

Calcium supplementation programs for pregnant women also need to be encouraged. Several studies have shown that high doses of calcium supplementation (1200 $\mathrm{mg} /$ day) can reduce the BLL in pregnant women (68) and prevent the occurrence of GH/PE (69). The World Health Organization (WHO) recommends calcium supplementation $(1,500-2,000 \mathrm{mg} /$ day $)$ in pregnant women from 20 weeks of gestation until the end of pregnancy. Especially, those who are at high risk of developing gestational hypertension should take the supplementation (70). The WHO also recommends calcium supplementation in pregnant women with BLL of $\geq 5 \mu \mathrm{g} / \mathrm{dL}$ and inadequate calcium intake (71).

Adequate calcium intake during pregnancy will prevent the occurrence of inadequacy of calcium resources in the bones (bone decalcification) so that the release of lead from the bones into the circulatory system can also be prevented. Calcium intake also plays a role in the blood pressure regulation by modifying calcium in vascular smooth muscle cells and regulating blood vessel volumes through the renin-angiotensinaldosterone system. The inadequate calcium intake will increase the activity of the parathyroid gland. The excessive parathyroid hormone also will increase intracellular calcium in vascular smooth muscle, which causes vasoconstriction and increases blood pressure (72).

Theoretically, the best effort to overcome the impact of exposure to toxic substances in the environment is reducing the use of these toxic materials, for example, reduced use of lead, oil, pesticide and others in the electronics industry, battery industry. Another effort is reducing the contamination-risk factors 
in water, air, soil, food/drink, and objects around us. Research showed that remediation efforts, e.g., reducing the lead content in the soil in the battery recycling site, can reduce the BLL in children living around this location (73). However, implementing some of these alternative solutions is not easy. Thus, early detection of BLL in preconception period is the best solution besides calcium supplementation. The American College of Obstetricians and Gynecologists (ACOG) stated that pregnant and lactating women with current or previous BLL of $5 \mu \mathrm{g} / \mathrm{dL}$ or higher should get the intervention related to nutritional intake, especially calcium and iron supplementation (74).

Based the discussion, there is high risk of exposure to lead in pregnant women on the North Coast of Java in Brebes District. It has an impact on increasing BLL and blood pressure (GH/PE). The limitation of this study is that there was no measurement of oxidative stress parameters, such as levels of ROS and NO, or endothelin which can more accurately describe the mechanism of GH/PE because of exposure to lead. The cross-sectional design used in this study also caused the temporality aspect to be uncertain, whether exposure to lead occurred before the occurrence of GH/PE was not identified. To analyze the impact of exposure to lead on the health of pregnant women, fetal growth, further cohort studies need to investigate delivery process, pregnancy outcomes, and even the quality of child development in the first trimester of pregnancy.

\section{ACKNOWLEDGEMENTS}

The research team would like to express the deepest gratitude to the Directorate of Public Nutrition, Indonesian Ministry of Health for funding the research. We also thanked the Brebes District Health Office, all staff, and all the research subjects for their support.

\section{CONCLUSION}

The BLL in pregnant women with GH/PE is higher than normal pregnant women, and the BLL in the high category $(\geq 35.15 \mu \mathrm{g} / \mathrm{dL}$ ) is an independent risk factor for GH/PE. For better preventive efforts, BLL screening should be carried out in high-risk women or in the pre-conception period itself. Further, the calcium supplementation program can be done earlier, starting from the first trimester of pregnancy.

\section{REFERENCES}

1. World Health Organization. Trends in Maternal Mortality 2000 To 2017. Switzerland: World Health Organization; 2019. 1-16 p. https://apps.who.int/ iris/handle/10665/327596
2. World Health Organization. Maternal Mortality: Fact sheet. Switzerland: World Health Organization; 2014. 1-4 p. https://apps.who.int/iris/bitstream/ handle/10665/112318/WHO_RHR_14.06_eng.pdf

3. Say L, Chou D, Gemmill A, Tunçalp Ö, Moller A, Daniels J, et al. Global Causes of Maternal Death: A WHO Systematic Analysis. Lancet Glob Heal. 2014;2(6):e323-e333. http://dx.doi.org/10.1016/ S2214-109X(14)70227-X

4. The American College of Obstetricians and Gynecologists. Hypertension in Pregnancy. Washington DC: The American College of Obstetricians and Gynecologists; 2013. 1-89 p. http://www.spog.org.pe/web/phocadownloadpap/ HypertensioninPregnancy.pdf

5. Brown M, Magee L, Kenny L, Karumanchi S, McCarthy F, Saito S, et al. Hypertensive Disorders of Pregnancy: ISSHP Classification, Diagnosis, and Management Recommendations for International Practice. Hypertension. 2018;72(1):24-43. https:// doi.org/10.1161/hypertensionaha.117.10803

6. World Health Organization. WHORecommendations for Prevention and Treatment of Pre-Eclampsia and Eclampsia. Geneva: World Health Organization; 2011. 1-46 p. https://www.ncbi.nlm.nih.gov/books/ NBK140561/

7. Braunthal S, Brateanu A. Hypertension in Pregnancy: Pathophysiology and Treatment. SAGE Open Med. 2019;7(1):1-15. https://doi. org/10.1177/2050312119843700

8. The American College of Obstetricians and Gynecologists. Gestational Hypertension and Preeclampsia. Obstetrics \& Gynecology. 2020;135(6):e237-e260. https://doi.org/10.1097/ AOG.0000000000003891

9. Ledda C, Fiore M, Santarelli L, Bracci M, Mascali G, Agati M, et al. Gestational Hypertension and Organophosphorus Pesticide Exposure: A CrossSectional Study. Biomed Res Int. 2015;2015(1):1-5. https://dx.doi.org/10.1155/2015/280891

10. Spadarella E, Leso V, Fontana L, Giordano A, lavicoli I. Occupational Risk Factors and Hypertensive Disorders in Pregnancy: A Systematic Review. Int J Environ Res Public Health. 2021;18(16):1-33. https://doi.org/10.3390/ijerph18168277

11. Gajewska K, Laskowska M, Almeida A, Pinto E, Skórzyńska-Dziduszko K, Błażewicz A. Lead Levels in Non-Occupationally Exposed Women with Preeclampsia. Molecules. 2021;26(10):1-10. https://doi.org/10.3390/molecules26103051

12. Disha, Sharma S, Goyal M, Kumar P, Ghosh R, Sharma P. Association of Raised Blood Lead Levels in Pregnant Women with Preeclampsia: A Study at Tertiary Centre. Taiwan J Obstet Gynecol. 2019;58(1):60-63. tjog.2018.11.011

https://doi.org/10.1016/j.

13. Bayat $F$, Akbari $S$, Dabirioskoei A, Nasiri M, Mellati A. The Relationship between Blood Lead Level and Preeclampsia. Electronic Physician. 2016;8(12):3450-3455. http://dx.doi. org/10.19082/3450

14. Lopes A, Peixe T, Mesas A, Paoliello M. Lead 
Exposure and Oxidative Stress: A Systematic Review. In: de Vogt $P$, editor. Switzerland: Springer Cham; 2016. 193-238 p. https://doi. org/10.1007/978-3-319-20013-2_3

15. Touyz R, Rios F, Alves-Lopes R, Neves K, Camargo L, Montezano A. Oxidative Stress: A Unifying Paradigm in Hypertension. Can J Cardiol. 2020;36(5):659-670. https://doi.org/10.1016/j. cjca.2020.02.081

16. Rodrigo R, Brito R, González J. Oxidative Stress and Essential Hypertension. In: Salazar-Sanchez L, editor. London: IntechOpen Limited; 2016.27-47 p. http://dx.doi.org/10.5772/64079

17. ASEANstats. ASEAN Maternal Mortality Rate: ASEAN Statistical Yearbook 2015. Jakarta: The ASEAN Secretariat; 2016. https://www.aseanstats. org/publication/asean-maternal-mortality-rateinfographic

18. Ministry of National Development Planning. Roadmap of SDGs Indonesia: A Highlight. Jakarta: Ministry of National Development Planning; 2019. 1-124 p. https://inff.org/resource/roadmap-of-sdgsindonesia-a-highlight

19. Daga G. Reducing Maternal Mortality in Indonesia of Post Modern Era. Jakarta: PT. Strategic Asia; 2013. 1-48 p. https://www.researchgate.net/ publication/256854365

20. Province Health Office of Central Java. Health Profile of Central Java Province 2019. Semarang: Province Health Office of Central Java; 2020. 1-230 p. https://dinkesjatengprov.go.id/v2018/ storage/2020/09/Profil-Jateng-tahun-2019.pdf

21. Regional Research and Development Planning Agency of Brebes Regency. Analysis of the Situation of Mother and Child (ASIA) in Brebes Regency in 2018. Brebes: Regional Research and Development Planning Agency of Brebes Regency; 2018.

22. Centers for Disease Control and Prevention. Guidelines for The Identification and Management of Lead Exposure in Pregnant and Lactating Women. In: Ettinger A, Wengrovitz A, editors. Atlanta: U.S. Department of Health and Human Services; 2010. 1-302 p. https://www.cdc.gov/ nceh/lead/publications/leadandpregnancy2010.pdf

23. Hananingtyas I. Studi Pencemaran Kandungan Logam Berat Timbal $(\mathrm{Pb})$ dan Kadmium (Cd) pada Ikan Tongkol (Euthynnus sp.) di Pantai Utara Jawa. Biotropic J Trop Biol. 2017;1(2):41-50. http://dx.doi. org/10.29080/biotropic.2017.1.2.41-50

24. Hartini E. Kadar Plumbum (Pb) dalam Umbi Bawang Merah di Kecamatan Kersana Kabupaten Brebes. J Visikes. 2011;10(1):69-75. https://doi. org/10.33633/visikes.v10i1.686

25. Haryanto B. Lead Exposure from Battery Recycling in Indonesia. Rev Environ Health. 2016;31(1):187190. http://dx.doi.org/10.1515/reveh-2015-0036

26. Florkowski C. Sensitivity, Specificity, ReceiverOperating Characteristic (ROC) Curves and Likelihood Ratios: Communicating The Performance of Diagnostic Tests. Clin Biochem Rev. 2008;29(Suppl 1):S83-S87. https://www.ncbi. nlm.nih.gov/pubmed/18852864

27. Hosmer D, Lemeshow S, Sturdivant R. Applied Logistic Regression. $3^{\text {rd }}$ ed. New Jersey: John Wiley \& Sons, Inc; 2013. 1-500 p. https://onlinelibrary. wiley.com/doi/book/10.1002/9781118548387

28. Al-Jameil N. Maternal Serum Lead Levels and Risk of Preeclampsia in Pregnant Women: A Cohort Study in A Maternity Hospital, Riyadh, Saudi Arabia. Int J Clin Exp Pathol. 2014;7(6):3182-3189. https:// www.ncbi.nlm.nih.gov/pubmed/25031738

29. Gambelunghe A, Sallsten G, Borné Y, Forsgard N, Hedblad B, Nilsson P, et al. Low-Level Exposure to Lead, Blood Pressure, and Hypertension in A Population-Based Cohort. Environ Res. 2016;149(1):157-163. https://doi.org/10.1016/j. envres.2016.05.015

30. Eka H, Mukono J. The Correlation between Blood Lead Level with Hypertension of Painting Cars Worker in Surabaya. J Kesehat Lingkung. 2017;9(1):65-74. http://dx.doi.org/10.20473/jkl. v9i1.2017.66-74

31. Ladele J, Fajolu I, Ezeaka V. Determination of Lead Levels in Maternal and Umbilical Cord Blood at Birth at The Lagos University Teaching Hospital, Lagos. PLoS One. 2019;14(2):1-21. http://dx.doi. org/10.1371/journal.pone.0211535

32. Center for Soil and Agroclimate Research and Development. Pollution of Agrochemicals Needs to be Watched. Warta Penelitian dan Pengembangan Pertanian Indonesia. 2003;25(6):13-14. http://203.190.37.42/publikasi/wr256038.pdf

33. Alengebawy A, Abdelkhalek S, Qureshi S, Wang M. Heavy Metals and Pesticides Toxicity in Agricultural Soil and Plants: Ecological Risks and Human Health Implications. Toxics. 2021;9(42):1-33. https://doi. org/10.3390/toxics 9030042

34. Pediatric Environmental Health Specialty Units. Recommendations on Management of Childhood LeadExposure.U.S.:PediatricEnvironmental Health Specialty Units; 2021. 1-6 p. https://www.pehsu. net/_Library/facts/PEHSU_Fact_Sheet_Lead_ Management_Health_Professionals 9_2021.pdf

35. Agency for Toxic Substances and Disease RegistryATSDR.LeadToxicity:CaseStudiesinEnvironmental Medicine (CSEM). 2017;WB2832(1):1-185. https:// www.atsdr.cdc.gov/csem/lead/docs/CSEM-Lead toxicity 508.pdf

36. Kumar A, Kaur S. Calcium: A Nutrient in Pregnancy. J Obstet Gynecol India. 2017;67(5):313-318. http:// dx.doi.org/10.1007/s13224-017-1007-2

37. Marangoni F, Cetin I, Verduci E, Canzone G, Giovannini M, Scollo P, et al. Maternal Diet and Nutrient Requirements in Pregnancy and Breastfeeding. An Italian Consensus Document. Nutrients. 2016;8(10):1-17. https://doi.org/10.3390/ $\underline{\text { nu8100629 }}$ 
38. National Institute of Health. Pregnancy, Breastfeeding, and Bone Health. U.S.: National Institute of Health; 2018. 1-3 p. https://www.bones. nih.gov/health-info/bone/bone-health/pregnancy

39. Sanz-Salvador L, García-Pérez M, Tarín J, Cano A. Bone Metabolic Changes During Pregnancy: A Period of Vulnerability to Osteoporosis and Fracture. Eur J Endocrinol. 2015;172(2):R53-R65. https://doi.org/10.1530/eje-14-0424

40. Phipps E, Prasanna D, Brima W, Jim B. Preeclampsia: Updates in Pathogenesis, Definitions, and Guidelines. Clin J Am Soc Nephrol. 2016;11(6):1102-1113. https://doi.org/10.2215/ cjn. 12081115

41. Simões $M$, Azevedo $B$, Alonso $M$, Salaices $M$, Vassallo D. Chronic Low-Level Lead Exposure Increases Mesenteric Vascular Reactivity: Role of Cyclooxygenase-2-Derived Prostanoids. Front Physiol. 2021;11(1):1-13. https://doi.org/10.3389/ fphys.2020.590308

42. Mannaerts D, Faes E, Cos P, Briedé J, Gyselaers W, Cornette J, et al. Oxidative Stress in Healthy Pregnancy and Preeclampsia is Linked to Chronic Inflammation, Iron Status and Vascular Function. PLoS One. 2018;13(9):1-14. https://doi. org/10.1371/journal.pone.0202919

43. Kennedy D, Woodland C, Koren G. Lead Exposure, Gestational Hypertension and Pre-eclampsia: A Systematic Review of Cause and Effect. J Obstet Gynaecol (Lahore). 2012;32(6):512-517. https:// doi.org/10.3109/01443615.2012.693987

44. Agency for Toxic Substances and Disease Registry. Toxicological Profile for Lead. U.S: Agency for Toxic Sustances and Disease Registry; 2020. 1-582 p. https://www.atsdr.cdc.gov/toxprofiles/tp13.pdf

45. McElwain C, Tuboly E, McCarthy F, McCarthy C. Mechanisms of Endothelial Dysfunction in PreEclampsia and Gestational Diabetes Mellitus: Windows Into Future Cardiometabolic Health? Front Endocrinol (Lausanne). 2020;11(1):1-19. https://doi.org/10.3389/fendo.2020.00655

46. Possomato-Vieira J, Khalil R. Mechanisms of Endothelial Dysfunction in Hypertensive Pregnancy and Preeclampsia.AdvPharmacol.2016;77(1):361431. https://doi.org/10.1016/bs.apha.2016.04.008

47. Das $S$, Das R, Bajracharya R, Baral G, Jabegu $\mathrm{B}$, Odland J, et al. Incidence and Risk Factors of Pre-eclampsia in The Paropakar Maternity and Women's Hospital, Nepal: A Retrospective Study. Int J Environ Res Public Health. 2019;16(19):1-8. https://doi.org/10.3390/ijerph16193571

48. Chasan-Taber $L$, Silveira $M$, Waring $M$, Pekow P, Braun B, Manson J, et al. Gestational Weight Gain, Body Mass Index, and Risk of Hypertensive Disorders of Pregnancy in a Predominantly Puerto Rican Population. Matern Child Health J. 2016;20(9):1804-1813. https://doi.org/10.1007/ s10995-016-1983-3

49. Shao $Y$, Qu J, Huang $H$, Mao B, Dai W, He X, et al. Pre-pregnancy BMI, Gestational Weight Gain and Risk of Preeclampsia: A Birth Cohort Study in Lanzhou, China. BMC Pregnancy Childbirth.
2017;17(1):1-8. https://doi.org/10.1186/s12884017-1567-2

50. Hrolfsdottir L, Schalkwijk C, Birgisdottir B, Gunnarsdottir I, Maslova E, Granström C, et al. Maternal Diet, Gestational Weight Gain, and Inflammatory Markers During Pregnancy. Obesity. 2016;24(10):2133-2139. https://doi.org/10.1002/ oby. 21617

51. Witteveen A, Henrichs J, Bellers $M$, van Oenen E, Verhoeven C, Vrijkotte T. Mediating Role of C-Reactive Protein in Associations Between PrePregnancy BMI and Adverse Maternal and Neonatal Outcomes: The ABCD-Study Cohort. The J Matern Neonatal Med. 2020;1(1):1-9. https://doi.org/10.10 80/14767058.2020.1807510

52. Whitaker K, Marino R, Haapala J, Foster L, Smith $\mathrm{K}$, Teague A, et al. Associations of Maternal Weight Status Before, During, and After Pregnancy with Inflammatory Markers in Breast Milk. Obesity. 2017;25(12):2092-2099. https://doi.org/10.1002/ oby. 22025

53. Phoswa W, Khaliq O. The Role of Oxidative Stress in HypertensiveDisordersofPregnancy(Preeclampsia, Gestational Hypertension) and Metabolic Disorder of Pregnancy (Gestational Diabetes Mellitus). Oxid Med Cell Longev. 2021;2021(1):1-10. https://doi. org/10.1155/2021/5581570

54. Guerby P, Tasta O, Swiader A, Pont F, Bujold $E$, Parant $O$, et al. Role of Oxidative Stress in The Dysfunction of The Placental Endothelial Nitric Oxide Synthase in Preeclampsia. Redox Biol. 2021;40(1):1-14. https://doi.org/10.1016/j. redox.2021.101861

55. Wang N, Chen C, Nie X, Han B, Li Q, Chen Y, et al. Blood Lead Level and Its Association With Body Mass Index and Obesity in China - Results from SPECT-ChinaStudy. ScientificReports. 2015;5(1):115. http://dx.doi.org/10.1038/srep18299

56. Wang G, Dibari J, Bind E, Steffens A, Mukherjee $\mathrm{J}$, Azuine R, et al. Association between Maternal Exposure to Lead, Maternal Folate Status, and Intergenerational Risk of Childhood Overweight and Obesity. JAMA Netw Open. 2019;2(10):1-14. http://doi:10.1001/jamanetworkopen.2019.12343

57. Masschelin P, Cox A, Chernis N, Hartig S. The Impact of Oxidative Stress on Adipose Tissue Energy Balance. Front Physiol. 2020;10(1):1-8. https://doi.org/10.3389/fphys.2019.01638

58. Balali-Mood M, Naseri K, Tahergorabi Z, Khazdair M, Sadeghi M. Toxic Mechanisms of Five Heavy Metals: Mercury, Lead, Chromium, Cadmium, and Arsenic. Front Pharmacol. 2021;12(1):1-19. http:// dx.doi.org/10.3389/fphar.2021.643972

59. Yadav G, Chambial S, Agrawal N, Gothwal M, Kathuria P, Singh P, et al. Blood Lead Levels in Antenatal Women and Its Association with Iron Deficiency Anemia and Adverse Pregnancy Outcomes. J Fam Med Prim Care. 2020;9(6):31063111. https://doi.org/10.4103/jfmpc.jfmpc 7820

60. Col Madendag I, Eraslan Sahin M, Madendag Y, Sahin E, Demir M, Acmaz B, et al. The Effect of Iron Deficiency Anemia Early in the Third 
Trimester on Small for Gestational Age and Birth Weight: A Retrospective Cohort Study on Iron Deficiency Anemia and Fetal Weight. Biomed Res Int. 2019;2019(1):1-4. http://dx.doi. org/10.1155/2019/7613868

61. World Health Organization. The Global Prevalence of Anaemia in 2011. Geneva: World Health Organization; 2015. 1-48 p. https://apps.who.int/ iris/handle/10665/177094

62. Curry S, Krist A, Owens D, Barry M, Cabana M, Caughey A, et al. Screening for Elevated Blood Lead Levels in Children and Pregnant Women: US Preventive Services Task Force Recommendation Statement. JAMA - J Am Med Assoc. 2019;321(15):1502-1509. https://doi.org/10.1001/ jama.2019.3326

63. Minnesota Department of Health. Blood Lead Screening GuidelinesforPregnantandBreastfeeding Women in Minnesota. St. Paul: Minnesota Department of Health; 2015. 1-22 p. https://www. health.state.mn.us/communities/environment/lead/ docs/reports/pregnancyguidelines.pdf

64. Taylor C, Tilling K, Golding J, Emond A. Low Level Lead Exposure and Pregnancy Outcomes in An Observational Birth Cohort Study: Dose-Response Relationships. BMC Res Notes. 2016;9(1):1-5. https://doi.org/10.1186/s13104-016-2092-5

65. Donzelli G, Carducci A, Llopis-Gonzalez A, Verani M, Llopis-Morales A, Cioni L, et al. The Association Between Lead and Attention-Deficit/Hyperactivity Disorder: A Systematic Review. Int J Environ Res Public Health. 2019;16(3):1-14. https://doi. org/10.3390/ijerph16030382

66. Park J, Seo J, Hong Y, Kim Y, Kang J, Yoo J, et al. Blood Lead Concentrations and Attention Deficit Hyperactivity Disorder in Korean Children: A Hospital-Based Case Control Study. BMC Pediatr. 2016;16(1):1-7. http://dx.doi.org/10.1186/s12887016-0696-5

67. Shah-Kulkarni S, Ha M, Kim B, Kim E, Hong Y, Park $\mathrm{H}$, et al. Neurodevelopment in Early Childhood
Affected by Prenatal Lead Exposure and Iron Intake. Med (United States). 2016;95(4):1-9. https://doi. org/ $10.1097 / \mathrm{md} .0000000000002508$

68. Ettinger $\mathrm{A}$, Lamadrid-Figueroa $\mathrm{H}$, Téllez-Rojo M, Mercado-García A, Peterson K, Schwartz $\mathrm{J}$, et al. Effect of Calcium Supplementation on Blood Lead Levels in Pregnancy: A Randomized Placebo-Controlled Trial. Environ Health Perspect. 2009;117(1):26-31. $\quad$ https://doi.org/10.1289/ ehp. 11868

69. Omotayo M, Dickin K, O'Brien K, Neufeld L, De Regil L, Stoltzfus R. Calcium Supplementation to Prevent Preeclampsia: Translating Guidelines Into Practice in Low-income Countries. Adv Nutr. 2016;7(2):275278. http://dx.doi.org/10.3945/an.115.010736

70. World Health Organization. Guideline: Calcium Supplementation in Pregnant Women. Geneva: World Health Organization Press; 2013. 1-35 p.

71. World Health Organization. WHO Guideline for Clinical Management of Exposure to Lead: Executive Summary. Geneva: World Health Organization; 2021. 1-16 p. https://www.who.int/publications/i/ item/9789240037045

72. Villa-Etchegoyen $C$, Lombarte $M$, Matamoros $N$, Belizán J, Cormick G. Mechanisms Involved in The Relationship Between Low Calcium Intake and High Blood Pressure. Nutrients. 2019;11(5):1-16. https://doi.org/10.3390/nu11051112

73. Chowdhury K, Nurunnahar S, Kabir M, Islam M, Baker M, Islam M, et al. Child Lead Exposure Near Abandoned Lead Acid Battery Recycling Sites in A Residential Community in Bangladesh: Risk Factors and The Impact of Soil Remediation on Blood Lead Levels. Environ Res. 2021;194(1):1-10. https://doi. org/10.1016/j.envres.2020.110689

74. The American College of Obstetricians and Gynecologists. Lead Screening During Pregnancy and Lactation. Obstet Gynecol. 2012;120(2):416-420. https://doi.org/10.1097/ aog.0b013e31826804e8 